УДК $378.013+370.711$

Пономарьова Наталія Олександрівна

кандидат педагогічних наук, доцент, докторант кафедри початкової, дошкільної та професійної освіти Харківський національний педагогічний університет імені Г. С. Сковороди, м. Харків, Україна ORCID ID 0000-0002-0172-8007

ponomna@gmail.com

\title{
ГОТОВНІСТЬ ВЧИТЕЛЯ ІНФОРМАТИКИ ДО ПРОФОРІЄНТАЦІЙНОӤ РОБОТИ НА ІТ-СПЕЦІАЛЬНОСТІ ЯК ПЕДАГОГІЧНА ПРОБЛЕМА
}

\begin{abstract}
Анотація. У сучасних реаліях особливої значущості набуває проблема підготовки майбутніх учителів до профорієнтаційної роботи зі школярами. Статтю присвячено уточненню сутності готовності майбутніх учителів інформатики до здійснення профорієнтаційної роботи на ІТ-спеціальності зі школярами. У статті розкрито зміст основних компонентів (мотиваційного, когнітивного, практично-діяльнісного та рефлексивного) зазначеної готовності. У складі кожного 3 компонентів виділено інваріантну (базову, що не залежить від предметної спеціалізації вчителя і сфери професійної орієнтації) та варіативну (що враховує специфіку предметної галузі «Інформатика» та особливості ІТ-галузі як сфери професійної орієнтації) частини. Встановлена специфіка вказаних компонентів, яка має стати основою для подальшого обгрунтування й розробки практично затребуваної моделі підготовки майбутнього вчителя інформатики до професійної орієнтації школярів на ІТ-спеціальності.
\end{abstract}

Ключові слова: підготовка вчителя інформатики; профорієнтація школярів; профорієнтаційна робота; ІТ-спеціальності; готовність вчителя до профорієнтації; компоненти готовності до профорієнтації.

\section{1. ВСТУП}

Постановка проблеми. Однією з першочергових проблем, які нині стримують розвиток освітньої галузі в Україні, є недостатня відповідність освітніх послуг вимогам суспільства, запитам особистості, потребам ринку праці. Для стабільного розвитку і нового якісного прориву в національній системі освіти визнано необхідним, зокрема, забезпечити створення умов для посилення профорієнтаційної спрямованості навчально-виховного процесу в загальноосвітній школі [1]. Учитель $є$ безпосереднім організатором і втілювачем профорієнтаційної роботи в школі, а профорієнтаційна діяльність має бути невід'ємною складовою його педагогічної діяльності. Вищевикладене актуалізує питання формування готовності майбутніх учителів до здійснення профорієнтаційної роботи зі школярами.

Особливо гостро це стосується підготовки майбутнього вчителя інформатики, який виконує провідну роль у професійній орієнтації школярів на сучасні і вкрай затребувані для вітчизняної економіки IT-спеціальності. Підготовка висококваліфікованих фахівців для ІТ-індустрії є об'єктивною потребою розвитку як української, так і світової економіки.

Проведене вивчення специфіки сучасного стану відбору абітурієнтів на ITспеціальності дає підставу для висновків про те, що інтерес випускників до одержання IT-спеціальностей у закладах системи вищої освіти України не зростає; випускники залишаються недостатньо поінформованими стосовно особливостей підготовки ITспеціалістів у системі вищої освіти; спостерігаються прояви тенденції до зниження якості підготовки абітурієнтів, які вступають на IT-спеціальності; вирішення проблеми кадрового забезпечення ІТ-галузі потребує цілеспрямованої спільної роботи закладів середньої освіти, вищих навчальних закладів та роботодавців [2]. 
Низка опитувань учителів інформатики щодо профорієнтації як складової їх професійної діяльності, що проводилися в останнє десятиріччя в Україні, засвідчили непідготовленість педагогів до проведення на практиці ефективної профорієнтаційної роботи $з$ учнями [2], [3]. Разом 3 тим, здатність здійснювати педагогічний супровід процесів соціалізації і професійного самовизначення школярів визнано однією 3 предметних (спеціальних фахових) компетентностей учителя інформатики [4]. Отже, набуває актуальності підготовка вчителя інформатики до надання школярам підтримки у їх самостійному виборі професії в галузі ІТ-індустрії 3 урахуванням нахилів, інтересів, фізичних й інтелектуальних здібностей учнів та поточних і перспективних потреб ринку праці.

Аналіз останніх досліджень і публікацій. Проблеми професійної орієнтації молоді широко розглядаються у працях зарубіжних і вітчизняних учених.

У європейських і в більшості країн світу поняття «професійна орієнтація» переважно не використовується, а його аналогом виступає термін «Career Guidance» (керівництво, супровід кар'єри). Підготовка учнів шкіл до професійного самовизначення здійснюється там як складова загальної системи розвитку кар'єри «Career Development» - широкої сфери діяльності, яка включає в себе спеціалізовані установи, центри, заклади тощо, роботу яких забезпечують спеціально підготовлені фахівці-профоріснтатори [5], [6], [7].

В Україні, Росії, Білорусі та в інших пострадянських країнах професійна орієнтація школярів також розглядається як система заходів, спрямованих на активізацію процесу професійного самовизначення особистості, проте центром професійної орієнтації постає загальноосвітня школа, а найважливішу роль у цій роботі відграє вчитель. Розробці теоретичних i методичних засад здійснення профорієнтаційної роботи зі школярами присвячені праці I. П. Ареф'єва, В. П. Витязєва, Д. О. Закатнова, В. П. Зінченко, С. Т. Золотухіної, В. М. Мадзігона, Є. М. Павлютенкова, В. А. Рижова, Б. А. Сазонова, В. К. Сидоренка, В. Д. Симоненка,

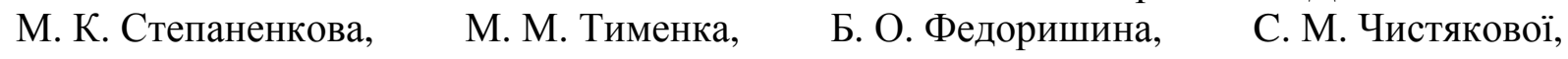
Г. І. Клімова, Б. С. Ханжарової, В. Б. Харламенко та інших.

Фундаментальні питання професійно-педагогічної підготовки майбутніх учителів і формування їх готовності до педагогічної діяльності висвітлені в наукових працях Ю. К. Бабанського, Г. О. Балла, М. Й. Боришевського, А. Д. Ганюшкіна, А. О. Деркача, К. М. Дурай-Новакової, М. І. Дьяченка, І .А. Зязюна, С. А. Калініна, Л. В. Кондрашової, О. І. Мешко, Н. Г. Ничкало, Л. Е. Орбан, I. Ф. Прокопенка, Л. Я. Рубіної, О. Я. Савченко, В.О. Сластьоніна та інших.

Проблеми підготовки майбутніх учителів інформатики до професійної діяльності, розвитку інформаційної культури та формування професійних компетентностей досліджували Н. В. Апатова, Л. І. Білоусова, І. Є. Булах, А. Ф. Верлань, Ю. В. Горошко, А. М. Гуржій, О. М. Гончарова, О.В.Данильчук, В М. Дем'яненко, Ю. О. Жук, І. С. Іваськів, В. А. Ізвозчиков, В. В. Осадчий, В. Д. Руденко, О. В. Співаковський, Є. М. Смірнова-Трибульська, Ю. В. Триус, Г. Ю. Цибко, М. І. Шкіль та інші. Методологічні засади здійснення підготовки майбутніх учителів інформатики розробляються у працях В. Ю. Бикова, М. І. Жалдака, О. М. Спіріна, В.В.Радула, В. В. Шовкуна, С. М. Овчарова, Н. В. Морзе та інших. На змісті й особливостях методичної підготовки вчителя інформатики зосереджені дослідження Н. Р. Балик, Л. В. Брескіной, Ю. С. Рамського, С. О. Семерікова, В.В.Лапінського, М. П. Лапчика та інших.

Проблеми підготовки майбутнього вчителя інформатики до профорієнтаційної роботи зі школярами, готовності майбутніх учителів до профорієнтаційної роботи зі школярами вивчалися О. О. Негріводою, Д.Ж. Завітренко, М. С. Чумаком, 
I. М. Чорною, Г. О. Шліхтою (Парховнюк), О.М.Пшеничновим, Б. М. Утегеновою, Л. В. Курочкіною, Л. В. Тименко та іншими. Однак, питання готовності майбутніх учителів інформатики до здійснення професійної орієнтації школярів на ITспеціальності не знайшли належного відображення у роботах психологів і педагогів.

Мета статті: встановити зміст структурних компонентів готовності майбутнього вчителя інформатики до здійснення профорієнтаційної роботи на IT-спеціальності зі школярами.

\section{2. ТЕОРЕТИЧНІ ОСНОВИ ДОСЛІДЖЕННЯ}

Поняття готовності майбутніх учителів до професійної педагогічної діяльності є складним і багатоаспектним. Згідно з особистісним підходом, вчені визначають його як

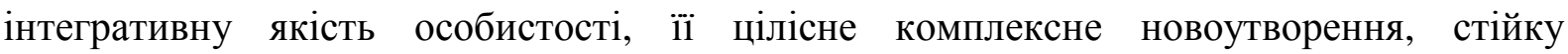
характеристику, комплекс індивідуально-психологічних якостей, систему знань, умінь та навичок, що сприяють успішній професійній діяльності і т. п. [8]. У працях О. О. Негріводи, Д. Ж. Завітренко, М. С. Чумака, І. М. Чорної, Г. О. Шліхти (Парховнюк), О. М. Пшеничнова, Б. М. Утегенової, Л. В. Курочкіної, Л. В. Тименко та інших зазначається, що важливою складовою професійної підготовки майбутніх учителів $є$ формування їх готовності до профорієнтаційної роботи зі школярами.

У психологічних дослідженнях І. М.Чорної психологічна готовність майбутнього вчителя до профорієнтаційної роботи описується як специфічний стан його особистості, що інтегрує в собі психологічну налаштованість та професійну підготовленість до здійснення даного виду діяльності [9].

Д.Ж. Завітренко та О.М. Пшеничнов сходяться у тлумаченні готовності майбутніх учителів до професійної орієнтації учнів основної школи як новоутворення в структурі особистості, що дає змогу майбутньому професіоналу виконувати певний вид діяльності, забезпечує ефективність виконання цієї діяльності, з'являється на певному рівні його особистісного розвитку, формується під впливом соціального середовища, навчання і виховання [10],[11].

М. С. Чумак, Б. М. Утегенова, Л. В. Курочкина визначають готовність майбутнього вчителя до профорієнтаційної роботи 3 учнями загальноосвітніх навчальних закладів як стійку інтегративну якість особистості. М. С. Чумак характеризує iï усвідомленим прагненням i спрямованістю на організацію профорієнтаційної роботи, здатністю прогнозувати i створювати умови для самостійного вибору учнями індивідуальної траєкторії професійного розвитку, його стимулювання, формування і корекції, сформованістю педагогічної рефлексії і високим рівнем оволодіння психолого-педагогічними і спеціальними знаннями, відповідними вміннями і навичками, які забезпечують успішність виконання профорієнтаційних функцій, що проявляються у використанні, самостійному конструюванні і модифікації профорієнтаційних засобів, розробці диференційованих (індивідуалізованих) програм профорієнтації учнів на основі індивідуальних навчальних планів (індивідуальних освітніх маршрутів) [12]. Л. В. Курочкина вказує, що ця характеристика особистості виявляється в усвідомленні соціальної й особистісної значущості профорієнтаційної діяльності, наявності установки на надання сприяння учням в процесі професійного самовизначення, володінні загальнокультурними і професійними компетенціями, що забезпечують здатність до організації й аналізу результатів педагогічного супроводу професійного самовизначення школярів [13]. Б. М. Утегенова акцентує на значущості готовності до профорієнтаційної роботи для розвиваючого переходу студентівмайбутніх педагогів від професійної підготовки до професійної діяльності [14]. 
Досліджуючи готовність майбутніх учителів до профорієнтаційної роботи зі старшокласниками, О. О. Негрівода визначає ії як сукупність спеціальних знань, умінь, навичок, необхідних учителям для надання допомоги учням у виборі майбутньої професії у школі; самореалізацію в педагогічній діяльності; позитивне ставлення до профорієнтаційної роботи; свідоме бажання займатись нею; емоційну стійкість; урівноваженість; настанову на активні, цілеспрямовані дії [15].

Грунтуючись на результатах аналізу наукових джерел, можна зробити висновок про те, що готовність майбутнього учителя до проведення профорієнтаційної роботи зі школярами виявляється у сукупності необхідних для успішного виконання профорієнтаційної діяльності загальних і спеціальних знань, умінь та навичок, а також стійкому бажанні здійснювати цю діяльність та здатності оцінювати й підвищувати рівень власної підготовки неї.

\section{3. РЕЗУЛЬТАТИ ДОСЛІДЖЕННЯ}

Спираючись на уявлення про сутність готовності майбутнього учителя до проведення профорієнтаційної роботи зі школярами, визначимо структуру готовності майбутнього вчителя інформатики до професійної орієнтації на IT-спеціальності школярів.

Щодо визначення структурних компонентів готовності майбутнього учителя до проведення профорієнтаційної роботи зі школярами, то в психолого-педагогічних працях пропонуються різні точки зору на це питання. Проведений аналіз психологопедагогічних досліджень дає підстави до висновків про те, що більшість науковців єдині у поглядах на окреслення чотирьох компонентів (мотиваційного, рефлексивного, когнітивного та практично-діяльнісного) у структурі готовності майбутнього учителя до проведення профорієнтаційної роботи зі школярами [3], [9], [10], [13]. Перші два компоненти (мотиваційний і рефлексивний), за поглядами психолога Чорної I. М., відображають психологічну налаштованість, а останні два (когнітивний і практичнодіяльністний) - підготовленість майбутнього вчителя до здійснення профорієнтаційної роботи зі школярами [9].

Виходячи 3 чотирикомпонентної структури готовності майбутнього вчителя інформатики до проведення профорієнтаційної роботи зі школярами, схарактеризуємо iї складові, враховуючи спрямування профорієнтаційної роботи на ІТ-спеціальності.

На нашу думку, у компонентах такої готовності можна виділити інваріантну та варіативну частини. Інваріантна частина відтворює загальні психолого-педагогічні витоки проведення профорієнтаційної роботи вчителем з учнями незалежно від його предметної спеціалізації і сфери професійної орієнтації. Варіативна частина відображає специфіку предметної галузі «Інформатика», оскільки, перш за все, в іï рамках майбутній учитель відповідної спеціалізації проводить профорієнтаційну роботу, а також особливості IT-професій, у напряму яких здійснюється вчителем профорієнтаційна робота.

Мотиваційний компонент готовності майбутніх учителів до профорієнтаційної роботи зі школярами як необхідна передумова формування мотивів поведінки та діяльності особистості, на думку науковців, є одним із головних і визначає успішність діяльності [16].

Мотиваційна складова готовності майбутніх учителів інформатики до профорієнтаційної роботи зі школярами на IT-спеціальності - динамічна структура різноманітних спонукань і стимулів, які виступають у ролі рушійних сил цього напряму професійної діяльності вчителя. 
Існують різні підходи до тлумачення поняття мотивації, iï структури, шляхів іiі формування. Структуру мотиваційної сфери можна розглядати як таку, що складається з ієрархізованих складових: потреб, мотивів, цілей та інтересів. Кожна 3 цих складових має змістовні та динамічні характеристики. Зауважимо, що головною характеристикою мотиваційної сфери є саме мотиви як такі, що безпосередньо пов'язані зі смислом, особистою значущістю діяльності. Мотиваційна готовність учителя до професійної діяльності також обумовлюється цінностями - орієнтирами його соціальної і професійної активності [9].

Негрівода О. О. та інші мотиваційний компонент характеризують як позитивне ставлення до профорієнтаційної діяльності, свідоме бажання займатись нею, переконаність в іiі значенні; стійку ціннісну орієнтацію педагога на розв'язання профорієнтаційних проблем; стійку та усвідомлену потребу в оволодінні знаннями, уміннями, навичками, необхідними для успішного здійснення профоріснтаційної діяльності; прагнення домагатися успіхів, не зважаючи на можливі труднощі, пов'язані iз специфікою профорієнтаційної роботи; стійкий, глибокий інтерес до профорієнтаційної діяльності, бажання реалізувати в ній свої можливості [15], [16].

Отже, до складу інваріантної частини мотиваційного компоненту готовності майбутніх учителів інформатики до профорієнтаційної роботи зі школярами на ITспеціальності можна віднести сформовані потреби, мотиви, цілі, інтереси вчителя у проведенні профорієнтаційної роботи зі школярами.

Варіативна частина мотиваційного компоненту зазначеної готовності включатиме;

- розуміння вчителем соціальної й особистісної значущості ефективного вирішення проблеми професійного самовизначення школярів в IT-галузі;

- усвідомлення вчителем виключної ролі навчального предмету «Інформатика» у сприянні успішному професійного самовизначення учнів в IT-галузі та власної відповідальності за його педагогічну підтримку;

- сформовані особистісні якості вчителя, що забезпечують його активність, цілеспрямованість та наполегливість у здійсненні професійної орієнтації школярів на ІТ-спеціальності та готовність до власного професійного удосконалення у вказаному напрямі.

Сукупність знань, якими має володіти учитель інформатики для успішного здійснення профорієнтаційної роботи, утворює зміст когнітивного компоненту готовності майбутніх учителів до профорієнтаційної роботи зі школярами на ITспеціальності.

Щодо когнітивного компоненту готовності учителя до профорієнтаційної роботи, то він в цілому характеризується (за Негріводою О. О. та Шліхтою (Парховнюк) Г. О.) як усвідомлення цілей, реалізація яких забезпечить розв'язання певного завдання; усвідомлення й оцінка умов, за яких відбуватиметься профорієнтаційна діяльність, знання специфіки цієї роботи; актуалізація досвіду, пов'язаного з виконанням завдань i вимог подібного характеру; високий рівень інтелектуального розвитку, інтелектуальнологічні здібності, асоціативність сприймання, творче мислення, уява, інтуїція, незалежність суджень; професійна компетентність; теоретико-методологічна підготовка майбутніх учителів; система знань психологічних основ профорієнтаційної роботи у школі [15], [17].

Завітренко Д.Ж., досліджуючи проблему підготовки до профорієнтаційної діяльності учителів технологій, до цього компоненту включає передусім знання предмету і способів професійної діяльності у галузі професійної орієнтації, серед яких як найважливіші виділяє знання про вікові особливості учнів, специфіку педагогічного 
супроводження професійного самовизначення учнів, мінливість та різноманітність світу професій, кон'юнктуру ринку праці [10].

Узагальнюючи напрацювання вчених, до інваріантної (базової) складової когнітивного компоненту готовності майбутніх учителів інформатики до професійної орієнтації школярів на ІТ-спеціальності можна віднести знання вчителя щодо основ проведення професійної орієнтації школярів, що не залежать від його предметної спеціалізації і складають підвалини профорієнтаційної діяльності вчителя в рамках навчальної та позанавчальної роботи з учнями. Спираючись на дослідження психологів та педагогів, визначаємо інваріантну складову:

- знання сутності та специфіки процесу професійного самовизначення школярів;

- знання ключових принципів професійної орієнтації школярів;

- знання мети та змісту профорієнтаційної роботи зі школярами;

- знання основних видів профорієнтаційної діяльності та ефективних форм i методів їх реалізації у навчально-виховному процесі в школі.

Варіативна (предметно-орієнтована) складова когнітивного компоненту готовності вчителя інформатики до професійної орієнтації школярів на ITспеціальності містить знання, які враховують особливості IT-професій та профорієнтаційний потенціал шкільного предмету «Інформатика»:

- обізнаність про специфіку ІТ-галузі як сфери професійної орієнтації;

- знання змісту профорієнтаційної роботи вчителя інформатики на ITспеціальності на різних етапах її здійснення;

- знання сучасних форм, методів та засобів здійснення профорієнтаційної роботи на IT-спеціальності.

Практично-діяльнісний компонент готовності вчителя інформатики до профорієнтаційної роботи зі школярами на IT-спеціальності включає комплекс умінь, необхідних для їі здійснення.

Такий компонент готовності майбутнього вчителя до профорієнтаційної роботи зі школярами характеризується вченими як актуалізація всієї сукупності знань учителя, переведення їх «на мову практичних дій»; визначення на основі знань, досвіду та оцінки намічених умов діяльності найбільш ефективних способів, методів та прийомів розв'язання завдань такої роботи; як такий, що здійснюється через систему вмінь, професійно-важливих якостей та здібностей [15], [17].

Завітренко Д. Ж. цей компонент називає практичним і в ньому суттєвим вважає виявлення точності вмінь та навичок, розрізняючи загальнотрудові та спеціальні вміння. Спеціальні вміння передбачають здатність студента самостійно знаходити, користуватися та забезпечувати інформацією (про індивідуальні особливості учня, вимоги конкретної професії, попит на ринку праці тощо) процес педагогічного супроводження професійного самовизначення учнів основної школи [10].

Перелік та опис загальної системи умінь (організаційних, комунікативних, інформаційно-орієнтаційних, конструктивних, дослідницьких, діагностичних, корекційних) щодо профорієнтаційної роботи учителя інформатики зі школярами наведено у роботі Г. О. Шліхти (Парховнюк) [17].

На нашу думку, практично-діяльнісний компонент готовності вчителя інформатики до профорієнтаційної роботи зі школярами на ІТ-спеціальності слід також розглядати як сукупність інваріантних i варіативних умінь, що забезпечують безпосереднє проведення профорієнтаційної роботи зі школярами.

Інваріантні вміння за своєю сутністю є загальними психолого-педагогічними вміннями щодо практичного застосування теоретичних засад профорієнтаційної роботи зі школярами, а саме: 
- дослідницько-діагностичні уміння здійснювати вивчення особистості учня в контексті їх професійного самовизначення;

- проективні уміння забезпечувати конкретизацію мети та завдань профорієнтаційної роботи, добирати зміст профорієнтаційної роботи;

- організаційно-практичні уміння впроваджувати сучасні ефективні форми, методи та засоби профорієнтаційної роботи.

Варіативні вміння вчителя інформатики до профорієнтаційної роботи зі школярами на IT-спеціальності пов'язані з вираженою специфікою IT-галузі як сфери професійної орієнтації. До таких умінь вважаємо, що належать:

- прогностичні уміння відстежувати і визначати перспективні напрями розвитку ринку IT-професій;

- аналітичні уміння визначати професіографічні характеристики нових i наднових IT-професій;

- медіа-вміння критичного сприйняття, інтерпретації, аналізу й використання медіа інформації, пов'язаної з проблемою професійної орієнтації учнів на ITспеціальності;

- уміння виокремлювати у навчальному матеріалі предмету «Інформатика» новітні засоби профорієнтаційної роботи й органічно включати їх до навчального процесу;

- уміння координувати власну профорієнтаційну діяльність із сучасними формами профорієнтаційної роботи, що застосовуються вищими навчальними закладами та представниками IT-індустрії.

Рефлексивна складова готовності майбутніх учителів до профорієнтаційної роботи зі школярами відображає здатність учителя як до самооцінювання успішності цього напряму своєї професійної діяльності, так і до усвідомлення своєї підготовленості до неї і шляхів ії підвищення.

Чумак М. Є. до рефлексивного компоненту відносить здатність до самоконтролю власної профорієнтаційної діяльності дій з урахуванням специфіки профорієнтаційної роботи з учнями; самооцінки значущості своєї участі у вирішенні завдань професійної орієнтації та корекції власної профорієнтаційної діяльності [12].

Негрівода О. О. та Шліхта (Парховнюк) Г. О. підкреслюють значущість емоційновольового вираження цього компоненту й описують його як вплив емоцій і почуттів на забезпечення успішного перебігу й результативності профорієнтаційної діяльності; емоційну витримку в подоланні труднощів, пов'язаних зі специфікою профорієнтаційної роботи; впевненість у собі як у професіоналі; високий ступінь самоконтролю, саморегуляції емоційним станом, поведінкою в умовах вирішення проблем профорієнтаційної діяльності; здатність відчувати задоволення від профорієнтаційної роботи з учнями [15], [17].

Отже, рефлексивний компонент готовності майбутніх учителів до профорієнтаційної роботи зі школярами у його інваріантній частині можна описати як такий, що характеризує здатність вчителя до оцінювання результатів власної профорієнтаційної роботи та ступеня підготовленості до неї.

Варіативна частина рефлексивного компоненту готовності майбутнього вчителя інформатики до профорієнтаційної роботи зі школярами на IT-спеціальності визначає:

- спрямованість на критичний аналіз відповідності змісту своєї профорієнтаційної роботи зі школярами на IT-спеціальності суспільним умовам і вимогам поточного стану ринку праці, ;

- спроможність і налаштованість учителя на постійний пошук і впровадження нових форм, методів та засобів здійснення профорієнтаційної роботи на ITспеціальності. 
Зауважимо, що з огляду на динамічність розвитку IT-галузі як сфери професійної орієнтації (народження нових професій потребує постійного оновлення підходів до ознайомлення $з$ ними учнів і встановлення способів спрямування їхнього інтересу на набуття таких професій), специфічність рефлексивного компоненту виявляється також у збільшенні його вагомості в загальній структурі готовності майбутнього вчителя інформатики до профорієнтаційної роботи зі школярами на IT-спеціальності.

\section{4. ВИСНОВКИ ТА ПЕРСПЕКТИВИ ПОДАЛЬШИХ ДОСЛДЖЕНЬ}

У готовності майбутнього вчителя інформатики до проведення профорієнтаційної роботи на ІТ-спеціальності зі школярами, що виявляється в сукупності загальних і спеціальних знань, умінь та навичок, стійкому бажанні здійснювати цю діяльність і здатності оцінювати й підвищувати рівень власної підготовки, виокремлюють мотиваційний, когнітивний, практично-діяльнісний та рефлексивний компоненти.

У складі кожного 3 компонентів можна виділити інваріантну (базову, що не залежить від предметної спеціалізації вчителя і сфери професійної орієнтації) i варіативну (що враховує специфіку предметної галузі «Інформатика» й особливості ITгалузі як сфери професійної орієнтації) частини. Мотиваційний компонент готовності майбутніх учителів інформатики до профорієнтаційної роботи зі школярами на ITспеціальності включає сформовані загальні потреби, мотиви, цілі, інтереси вчителя у ії проведенні, а також розуміння вчителем соціальної й особистісної значущості ефективного вирішення проблеми професійного самовизначення школярів в IT-галузі; усвідомлення вчителем виключної ролі навчального предмету «Інформатика» у сприянні успішному професійному самовизначенні учнів в IT-галузі та власної відповідальності за його педагогічну підтримку; сформовані особистісні якості вчителя, що забезпечують його активність, цілеспрямованість та наполегливість у здійсненні професійної орієнтації школярів на IT-спеціальності й готовність до власного професійного вдосконалення у вказаному напрямі. Когнітивний компонент готовності майбутніх учителів інформатики до професійної орієнтації школярів на ITспеціальності включає загальні знання вчителя щодо основ проведення професійної орієнтації школярів, які складають підвалини його профорієнтаційної діяльності, а також предметно-орієнтовані знання стосовно професійної орієнтації школярів на ITспеціальності. Практично-діяльнісний компонент готовності вчителя інформатики до профорієнтаційної роботи зі школярами на IT-спеціальності також включає сукупність інваріантних i варіативних умінь, що забезпечують безпосереднє проведення профорієнтаційної роботи зі школярами. Рефлексивний компонент готовності вчителя інформатики до профорієнтаційної роботи зі школярами на IT-спеціальності набуває для нього особливої значущості й характеризує загальну здатність вчителя до оцінювання результатів його профорієнтаційної роботи й оцінювання ним власної підготовленості до здійснення такої діяльності, а також спроможність і налаштованість учителя на критичний аналіз змісту своєї профорієнтаційної роботи з учнями на ITспеціальності, постійний пошук нових форм, методів та засобів эїі здійснення.

Зміст цих компонентів, як засвідчили результати виконаного дослідження, має визначений специфічний характер, a ïx формування повинно цілеспрямовано відбуватися в процесі професійної підготовки майбутніх учителів інформатики, що повністю відповідає сучасним вимогам до підготовки педагогічних кадрів у системі вищої педагогічної освіти. Проведене уточнення структурних компонентів готовності майбутніх учителів інформатики до професійної орієнтації школярів на ITспеціальності $\epsilon$ основою для подальшого обгрунтування i розробки практично 
затребуваної моделі підготовки майбутнього вчителя інформатики до професійної орієнтації школярів на IT-спеціальності на засадах компетентісного підходу.

\section{СПИСОК ВИКОРИСТАНИХ ДЖЕРЕЛ}

[1] Національна стратегія розвитку освіти в Україні на 2012-2021 роки. [Електронний ресурс]. Доступно: http://www.kharkivosvita.net.ua/ files/Rozv_osviti.pdf. Дата звернення: Квіт. 09, 2017.

[2] Н. Пономарьова, «Відбір абітурієнтів на IT-спеціальності в Україні: стан і проблеми», Наукові записки. Серія: проблеми методики фізико-математичної і технологічної освіти, т. 10, № 3 , c.131-137, 2016.

[3] Г. Шліхта, «Стан підготовки майбутніх вчителів інформатики до профорієнтаційної діяльності із старшокласниками», Наукові записки Тернопільського національного педагогічного університету імені Володимира Гнатюка. Серія: Педагогіка, № 8, с. 63-66, 2008.

[4] Проект стандарту вищої освіти. 014.09 Середня освіта (Інформатика) (бакалавр). [Електронний pecypc]. Доступно: http://mon.gov.ua/activity/education/reforma-osviti/naukovo-metodichna-radaministerstva/proekti-standartiv-vishhoyi-osviti.html. Дата звернення: Квіт. 09, 2017.

[5] А. Муратова, «Профориентация учащихся: зарубежный опыт». [Електронний ресурс]. Доступно: www.cls-kuntsevo.ru/portal_proforientir/prof_obuch_uchashihsya_zarubezgom_zarub _opit.php. Дата звернення: 7 травня $2017 \mathrm{p}$.

[6] С. Толстогузов, «Опыт профориентационной работы за рубежом», Образование и наука, №.1(120), c. $151-165,2015$.

[7] Career Guidance. A Handbook For Policy Makers. [Електронний pecypc]. Доступно: http://www.oecd.org/edu/innovation-education/34060761.pdf. Дата звернення: Квіт. 09, 2017.

[8] Н. Олефіренко, Підготовка майбутніх учителів початкової школи до проектування дидактичних електронних ресурсів. Харків, Україна: ХНПУ імені Г.С.Сковороди, 2014..

[9] I. Чорна, « Формування психологічної готовності майбутнього вчителя до профорієнтаційної роботи у школі», автореф. дис. на здобуття наук. ступеня канд. псих. наук, НПУ імені М.П.Драгоманова, Київ, Україна, 2003.

[10] Д. Завітренко, «Формування в майбутніх вчителів технологій готовності до професійної орієнтації учнів основної школи», автореф. дис. на здобуття наук. ступ. канд. пед. наук, КДПУ імені Володимира Вінниченка, Кіровоград,Україна, 2013.

[11] А. Пшеничнов, «Формирование готовности к профориентационной работе с учащимися у студентов педагогического вуза», дис. канд. пед. наук, ГОУ ВПО «Шуйский государственный педагогический университет», Шуя, Россия, 2009.

[12] М. Чумак, «Рівні сформованості готовності до профорієнтаційної роботи 3 учнями загальноосвітніх навчальних закладів в умовах профілізації навчання та методи їх визначення». [Електронний pecypc]. Доступно: http://www.nbuv.gov.ua/old_jrn/soc_gum/znpkp_ped/ 2012_18/r2/p2_16.pdf. Дата звернення: Квіт. 09, 2017.

[13] Л. Курочкина, «Формирование готовности будущего педагога к деятельности классного руководителя по педагогическому сопровождению профессионального самоопределения старшеклассников», дис. канд. пед. наук, ФГБОУ ВПО «Марийский государственный университет», Йошкар-Ола, Россия, 2015.

[14] Б. Утегенова, «Педагогические условия формирования готовности будущих учителей к профориентационнои работе в школе», автореф. дис. на соискание учен. степ. канд. пед. наук, Челябинский государственный университет, Челябинск, Россия, 1993.

[15] О. Негрівода, «Підготовка майбутніх учителів до професійно орієнтаційної роботи зі старшокласниками», автореф. дис. на здобуття вчен. ступ. канд. пед. наук, Д3 «Південноукраїнський національний педагогічний університет ім. К. Д. Ушинського», Одеса, Україна, 2012.

[16] К. Віаніс-Трофименко, «Мотивація педагога як умова зростання професійної компетентності», у Педагогічні шляхи реалізаиії загальноєвропейських иінностей у системі освіти Украӥни, К. ВіанісТрофименко, Ред. Харків, Україна: Стиль-Издат, 2005, с. 36-42.

[17] Г. Парховнюк, «Компоненти готовності майбутнього вчителя інформатики до профорієнтаційної діяльності зі старшокласниками». [Електронний ресурс]. Доступно: http://vuzlib.com.ua/articles/book/27497-Komponenti_gotovnost\%D1\%96_majjbut/1.html. Дата звернення: Квіт. 09, 2017. 


\title{
ГОТОВНОСТЬ УЧИТЕЛЯ ИНФОРМАТИКИ К ПРОФОРИЕНТАЦИОННОЙ РАБОТЕ НА ИТ-СПЕЦИАЛЬНОСТИ КАК ПЕДАГОГИЧЕСКАЯ ПРОБЛЕМА
}

\author{
Пономарёва Наталья Александровна \\ кандидат педагогических наук, доцент, докторант кафедры начального, дошкольного и \\ профессионального образования \\ Харьковский национальный педагогический университет имени Г. С. Сковороды, г. Харьков, Украина \\ ORCID ID 0000-0002-0172-8007 \\ ponomna@gmail.com
}

\begin{abstract}
Аннотация. В современных реалиях особую значимость приобретает проблема подготовки будущих учителей к профориентационной работе со школьниками. Статья посвящена уточнению сущности готовности будущих учителей информатики к профориентационной работы со школьниками на IT-специальности. В статье раскрыто содержание основных структурных компонентов указанной готовности: мотивационного, когнитивного, практически-деятельностного и рефлексивного. В составе каждого из компонентов выделено инвариантную (базовую, не зависящую от предметной специализации учителя и сферы профессиональной ориентации) и вариативную (учитывающую специфику предметной области «Информатика» и особенности IT-отрасли как сферы профессиональной ориентации) части. Установленная специфика структурных компонентов должна стать основой для дальнейшей разработки практически востребованной модели подготовки будущего учителя информатики к профессиональной ориентации школьников на ІТ-специальности.
\end{abstract}

Ключевые слова: подготовка учителя информатики; профориентация школьников; профориентационная работа; ИТ-специальности; готовность учителя к профориентации; компоненты готовности к профориентации.

\section{THE READINESS OF FUTURE TEACHER OF INFORMATICS TO CAREER GUIDANCE ON IT-SPECIALTY AS A PEDAGOGICAL PROBLEM}

\author{
Nataliia O. Ponomarova \\ Professional education \\ G. S. Skovoroda Kharkiv National Pedagogical University, Kharkiv, Ukraine \\ ORCID ID 0000-0002-0172-8007 \\ ponomna@gmail.com
}

$\mathrm{PhD}$ in pedagogical sciences, Associate Professor, Doctorate student of Department of Primary, Pre-school and

\begin{abstract}
In today's realities, the problem of preparing future teachers to career guidance with pupils is of particular importance. The article is devoted to clarifying the essence of the readiness of future teachers of informatics to work career guidance of pupils on IT-specialty. The article disclosed the content of the main components of the same readiness: motivational, cognitive, practical-activity and reflective components. In the content of each of the components is selected the invariant part (base, independent of the subject of specialization of teachers and areas of career guidance) and variable part (which takes into account the specific of subject area "Informatics" and the features of IT- industry as a sphere of career guidance). The detected specificity of these components should become a basis for the further justification and development of the practically demanded model of preparation of the future teacher of informatics to career guidance of pupils on IT-specialty.
\end{abstract}

Keywords: preparation of future teachers of informatics; professional orientation of pupils; career guidance; IT-specialty; readiness of the teacher of informatics for career guidance; components of the readiness for professional orientation work. 


\section{REFERENCES (TRANSLATED AND TRANSLITERATED)}

[1] National Strategy for Education Development in Ukraine for 2012-2021. [Online]. Available: http://www.kharkivosvita.net.ua/ files/Rozv_osviti.pdf. Accessed on: Apr 9, 2017. (in Ukrainian)

[2] N. Ponomarova, «The selection of entrants for IT-profession in Ukraine: state and problems», Naukovi zapysky. Seriya: problemy metodyky fizyko-matematychnoyi i tekhnolohichnoyi osvity, vol.10, no. 3, pp. 131-137, 2016. (in Ukrainian)

[3] H. Shlikhta, «State of training of future teachers of informatics to professional orientation activities with senior pupils», Naukovi zapysky Ternopil's'koho natsional'noho pedahohichnoho universytetu imeni Volodymyra Hnatyuka. Seriya: Pedahohika, no. 8, pp. 63-66, 2008. (in Ukrainian)

[4] The Project of Standard of Higher Education. 014.09 Secondary Education (Informatics) (BA). [Online]. Available: $\quad$ http://mon.gov.ua/activity/education/reforma-osviti/naukovo-metodichna-radaministerstva/proekti-standartiv-vishhoyi-osviti.html. Accessed on: Apr 9, 2017. (in Ukrainian)

[5] A. Muratova, « Professional orientation of students: foreign experience», [Online]. Available: http://www.cls-kuntsevo.ru/portal_proforientir/prof_obuch_uchashihsya_zarubezgom_zarub_ opit.php. Accessed on: Apr 9, 2017. (in Russian).

[6] S. Tolstohuzov, « Career guidance experience abroad», Obrazovanye y nauka, vol. 1 (120), pp. 151-165, 2015. (in Russian)

[7] Career Guidance. A handbook for policy makers. [Online]. Available: http://www.oecd.org/edu/innovation-education/34060761.pdf. Accessed on: Apr 9, 2017. (in English)

[8] N. Olefirenko, Preparation of primary school teacher to design e-learning resources. Kharkiv, Ukraine : KhNPU by G.S.Skovoroda, 2014. (in Ukrainian)

[9] I. Chorna, «Formation of psychological readiness of the future teacher to professional orientation activity at school», The abstract of dissertation of PhD in Pedagogical science, NPU imeni M.P.Drahomanova, Kyyiv, Ukraine, 2003. (in Ukrainian)

[10] D. Zavitrenko, «Formation of future teachers of technology readiness for professional orientation of secondary school pupils», The abstract of dissertation of PhD in Psychological sciences, KDPU imeni Volodymyra Vinnychenka, Kirovohrad, Ukraine, 2013. (in Ukrainian)

[11] A. Pshenichnov, «Formation of readiness for the work of professional orientation with students of pedagogical university», dis. of PhD in Pedagogical science, HOU VPO «SHujskij gosudarstvennyj pedagogicheskij universitet», Shuya, Russia, 2009. (in Russian)

[12] M. Chumak, «Levels of formation of readiness for professional orientation work with pupils of secondary schools in the conditions of profiling learning and methods of determination». [Online]. Available: http://www.nbuv.gov.ua/old_jrn/soc_gum/znpkp_ped/ 2012_18/r2/p2_16.pdf. Accessed on: Apr 9, 2017. (in Ukrainian)

[13] L. Kurochkyna, «Formation of readiness of the future teacher for the activity of the class teacher on pedagogical support of professional self-determination of senior pupils», dis. of $\mathrm{PhD}$ in Pedagogical science, FHBOU VPO «Marijskij gosudarstvennyj universitet», Yoshkar-Ola, Russia, 2015. (in Russian)

[14] B. Utehenova, «Pedagogical conditions for the formation of readiness of future teachers for professional orientation work in the school», The abstract of dissertation of $\mathrm{PhD}$ in in Pedagogical science, CHelyabinskij gosudarstvennyj universitet, Chelyabynsk, Russia, 1993. (in Russian)

[15] O. Nehrivoda, «Preparing future teachers for professional orientation work with high school students», The abstract of dissertation of PhD in Pedagogical science, DZ «Pivdennoukrayins'kyy natsional'nyy pedahohichnyy universytet im. K. D. Ushyns'koho», Odesa, Ukraine, 2012. (in Ukrainian).

[16] K.Vianis-Trofymenko, «Components of readiness of the future teacher of informatics to professional orientation activities with high school students», in Pedagogical ways to implement the European values in the education system of Ukraine, K. B. Vianis-Trofymenko, Ed. Kharkiv, Ukraine: Styl'-Yzdat, 2005, pp. 36-42. (in Ukrainian)

[17] H. Parkhovnyuk, «Components of readiness of the future teacher of informatics to professional orientation activities with high school students». [Online]. Available: https://core.ac.uk/ download/pdf/12082866.pdf. Accessed on: Apr 9, 2017. (in Ukrainian)

\section{(cc) BY-NC-SA}

This work is licensed under Creative Commons Attribution-NonCommercial-ShareAlike 4.0 International License. 